\title{
Social Networking as a New Trend in E-Marketing
}

\author{
T. Andrew Yang, Dan J. Kim and Vishal Dhalwani \\ University of Houston - Clear Lake, Houston 77204, Texas, USA \\ \{yang,kimdan\}@uhcl.edu
}

\begin{abstract}
In the world of e-marketing, new business models are frequently introduced, and new trends have started to emerge. One such latest trend is social networking websites, many of which have attracted not only large number of users and visitors, but also online advertising companies to place their ads on the sites. In this paper we explore online social networking as a new trend of e-marketing. We first examine the online social network as a new form of web-based services, and compare social networks with other representative web-based services by using the $7 \mathrm{C}$ framework. We then analyze social networking from a business strategy point of view, by creating a business model for online social networking sites using Porter's Five Forces Model. We also discuss the primary revenue models that may be used by organizations and companies providing online social networking services.
\end{abstract}

Keywords: Enterprise social networks, Marketing and campaign management, Value analysis

\section{INTRODUCTION}

Innovation sells! That is especially true in the Internet world. Since its inception, there have been lots of innovations and new applications in the Internet. Those innovations have caused major changes in our everyday lives, which can be easily felt across a myriad of applications, including education, shopping, entertainment, learning, banking, investing, etc. To see how web-based applications and services have evolved, we only need to compare the web sites that existed 6 or 7 years ago to the ones that exist today. One of the recent innovations in web-based applications is the online social networking services. In Table 1, we examine the progress of some representative web-based services, from the earliest static web pages (1995) to today's online services, including e-commerce sites and online social networks. Also shown are the respective years of inception, example sites, and supporting tools, for each of the representative services.

In general, a social network can be defined as a social structure made of nodes, which are usually individuals or organizations tied by one or more specific types of relations, such as financial exchange, friendship, passion, trade, web links, airline routes, hobbies, etc. Social networks connect people with all different types of interests, and one area that is expanding in the use of these networks is the corporate

Please use the following format when citing this chapter:

Yang, T. A., Kim, D. J., Dhalwani, V., 2007, in IFIP International Federation for Information Processing, Volume 255. Research and Practical lssues of Enterprise Information Systems II Volume 2, eds. L. Xu, Tjoa A., Chaudhry S. (Boston: Springer), pp. 847-856. 
environment. Businesses are beginning to use social networks as a means to help employees to connect, or customers to obtain information or help. Business companies using social networking services to support their products or customer services may be becoming a new trend. A good indication of this trend is CISCO's latest acquisitions of Tribe.net, an almost forgotten social networking site, and Five Across, a developer of social networking software. The buzz in the market is that CISCO will be using both platforms to help their corporate clients to build their own social networks.

Table 1. Progress of Web-based Services, plus Examples and Supporting Tools

\begin{tabular}{|l|l|l|}
\hline \multicolumn{1}{|c|}{ Web-based services } & \multicolumn{1}{|c|}{$\begin{array}{c}\text { Year of } \\
\text { inception }\end{array}$} & \multicolumn{1}{|c|}{ Example services / tools } \\
\hline 1. Static Web Sites (SWS) & Early 1990s & $\begin{array}{l}\text { The first commercial web browser, Netscape } \\
\text { Navigator, was launched in 1995. }\end{array}$ \\
\hline 2. Interactive Web Sites (WWS) & $1995 / 1996$ & Java applets, Java scripts, VB scripts, ... \\
\hline 3. Search Engines (SE) & 1995 & Lycos, Yahoo, ..., Google (1998) \\
\hline 4. Discussion Groups (DG) & 1995 & Yahoo groups, Google groups \\
\hline 5. E-Commerce Sites (EC) & 1995 & Amazon.com, e-Bay, ... \\
\hline 6. Online Social Networks (OSN) & Early 2000s & $\begin{array}{l}\text { MySpace (2003), LinkedIn (2003), Facebook } \\
\text { (2004), Ning (2005), Flickr, YouTube, ... }\end{array}$ \\
\hline
\end{tabular}

In addition to social networks used by companies to provide employee or customer services, popular online social network sites, such as MySpace.com and Ning.com, also attract online ads from retailers and corporations, which place online ads on the social network sites to take advantage of the large volume of visits by potential customers at the sites. Placing online ads on websites has been around since the beginning of the Web. Websites such as Yahoo and Google are capable of providing attractive (and usually free) services, and by doing so generating large volume of visits from web surfers all around the world. The large volume of traffic in turn attracts business companies to place their online ads on the site.

The success of Google is probably one of the most interesting Internet phenomena in the past decade. Starting in $1998^{1}$ as a startup search engine company, Google has since grown into a $\$ 150$ billion enterprise ${ }^{2 \cdot 3}$. Part of Google's success is based on its business model of providing free search engine to web surfers. By attracting large number of users to use its search engine, Google is able to charge an advertiser fees by placing its online ads on the Google site and/or by having the guarantee that the advertiser's website will appear in the top portion of the search results [1].

In 2005, Intermix Media, the company that owned MySpace.com, was acquired by News Corp. for the price of $\$ 580$ million ${ }^{4.5}$. At that time MySpace.com was ranked as the fifth most frequently visited website in terms of page views ${ }^{5}$. One and a half year later (in July 2006), MySpace reached the top spot as the most visited site in the U.S. ${ }^{6}$ It is certainly reasonable to anticipate that such large volume of online traffic will help to generate large online ads revenue. People have been wondering whether the success of Google and other online search sites would be duplicated in online social

\footnotetext{
'See http://www.google.com/corporate/history.html

${ }^{2}$ See http://finance.yahoo.com/q/ks? $\mathrm{s}=\mathrm{Goog}$

${ }^{3}$ Hoover's profile of Google, http://www.answers.com/topic/google?cat=biz-fin

${ }^{4} \mathrm{http}: / /$ www.newscorp.com/news/news_251.html

${ }^{5}$ http://www.internetnews.com/bus-news/article.php/3520866

${ }^{6}$ http://www.answers.com/MySpace?cat=biz-fin
} 
network sites. That same question has been asked by others in different ways: "How will MySpace, Facebook, or YouTube make money?" "Do social networks or usergenerated sites have legs like search engines?" [2] All those questions are apparently related to the existence of business model(s) for social networking sites. In answering the question "Why are venture capitalists pumping money into social networking start-ups?", Mark Pincus (the founder of the Tribe online social networking site) pointed out, "There's an intended business model in subscriptions, classifieds and even targeted advertising." [3]

The goal of our work is to study online social networking sites as a new trend of emarketing by applying existing frameworks (such as Rayport and Jaworski's 7C's [4]) and business models (such as the Five Forces Model [5]). In the rest of this paper, we first review the 7C framework, which is often used as a reference framework for ecommerce applications [6]. The representative web-based services (as shown in Table 1) are compared using the $7 \mathrm{C}$ framework. We then discuss examples of online social networks, and business models, including primary revenue models and the Five Forces Model. The Five Forces Model is applied to a sample online social networking site, Ning.com. The paper concludes with a summary and future work.

\section{THE 7C FRAMEWORK}

As shown in Table 2, the $7 C$ Framework is a model for understanding the role played by each of the seven interface design elements in a web-based system, especially in an e-commerce application.

Table 2. 7C Framework [6]

\begin{tabular}{|l|l|}
\hline $\begin{array}{l}\text { Interface } \\
\text { Elements }\end{array}$ & \multicolumn{1}{|c|}{ Meaning / Types (Examples) } \\
\hline Context & $\begin{array}{l}\text { How the site is organized, and how the content is presented to the users? a. } \\
\text { Functionalities: layout, performance b. Aesthetics (look-and-feel): color schemes, } \\
\text { visual themes }\end{array}$ \\
\hline Content & $\begin{array}{l}\text { What are offered by the site? Offering mix is the mix of product and service } \\
\text { information; Appeal mix refers to the mix of promotional messages; Multimedia } \\
\text { mix deals with the mix of various types of media; Content type refers to the degree } \\
\text { of time-sensitivity [6] }\end{array}$ \\
\hline Community & $\begin{array}{l}\text { User-to-user communications: Interactive (instant messaging, message boards, } \\
\text { member-to-member emailing lists) versus non-interactive communications }\end{array}$ \\
\hline Customization & $\begin{array}{l}\text { The site's ability to tailor itself (tailoring) or to be tailored by each user } \\
\text { (personalization) [6] }\end{array}$ \\
\hline Communication & $\begin{array}{l}\text { Site-to-user communications: Broadcast, Interactive, and Hybrid } \\
\text { The extent of formal linkage from one site to others: outsourced content, percent of } \\
\text { home site content, and pathways of connection [6] }\end{array}$ \\
\hline Commection & $\begin{array}{l}\text { The interface that supports the various aspects of } \\
\text { e-commerce, such as a shopping cart, security, order tracking, etc. }\end{array}$ \\
\hline
\end{tabular}

Each of the elements represents a specific component of the system, including context (how the site is designed), content (what information are presented), community (how users communicate with each other), customization (is the site customizable), communication (how the site communicate with the user), connection (how the site is related to other sites), and commerce (e-commerce functionalities). 
As shown in Table 3, we have performed a comparison of the six representative web-based services (Table 1), by using the 7C Framework as the reference model.

Table 3. Analysis of Web-based Services, Using the 7C Framework as the Reference Model

\begin{tabular}{|c|c|c|c|c|c|c|c|}
\hline $\begin{array}{l}\text { Ser- } \\
\text { vice }\end{array}$ & Context & Content & Community & $\begin{array}{c}\text { Customi- } \\
\text { zation }\end{array}$ & $\begin{array}{c}\text { Communi- } \\
\text { cation }\end{array}$ & $\begin{array}{l}\text { Conne } \\
\text { ction }\end{array}$ & Commerce \\
\hline 㞭葋 & $\begin{array}{l}\text { Linking bctween } \\
\text { pages, coloring, } \\
\text { some graphics }\end{array}$ & $\begin{array}{l}\text { Static } \\
\text { content }\end{array}$ & $\begin{array}{l}\text { Interactive } \\
\text { (User-to- } \\
\text { Admin } \\
\text { emails) }\end{array}$ & $\mathrm{N} / \mathrm{A}$ & $\begin{array}{l}\mathrm{N} / \mathrm{A}, \text { or } \\
\text { Interactive } \\
\text { (email- } \\
\text { discussions) }\end{array}$ & $\begin{array}{l}\text { Online } \\
\text { ads }\end{array}$ & $\mathrm{N} / \mathrm{A}$ \\
\hline 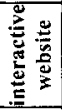 & $\begin{array}{l}\text { Linking between } \\
\text { pages, coloring, } \\
\text { graphics + } \\
\text { animation }\end{array}$ & $\begin{array}{l}\text { Static + } \\
\text { dynamic } \\
\text { content }\end{array}$ & $\begin{array}{l}\text { Interactive } \\
\text { (Uscr-to- } \\
\text { Admin } \\
\text { emails) } \\
\end{array}$ & $\mathrm{N} / \mathrm{A}$ & $\begin{array}{l}\text { N/A, or } \\
\text { Interactive } \\
\text { (email- } \\
\text { discussions) }\end{array}$ & $\begin{array}{l}\text { Online } \\
\text { ads }\end{array}$ & $\mathrm{N} / \mathrm{A}$ \\
\hline 昰 & $\begin{array}{l}\text { Linking between } \\
\text { pages, coloring, } \\
\text { graphics, } \\
\text { animation + } \\
\text { Query/response }\end{array}$ & $\begin{array}{l}\text { Query } \\
\text { results }\end{array}$ & $\begin{array}{l}\text { Interactive } \\
\text { (User-to- } \\
\text { Admin } \\
\text { emails) }\end{array}$ & $\begin{array}{l}\text { Some } \\
\text { personaliza } \\
\text { tion and } \\
\text { tailoring }\end{array}$ & $\begin{array}{l}\mathrm{N} / \mathrm{A}, \text { or } \\
\text { Interactive } \\
\text { (email- } \\
\text { discussions) }\end{array}$ & $\begin{array}{l}\text { Online } \\
\text { ads }\end{array}$ & N/A \\
\hline 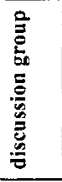 & $\begin{array}{l}\text { Linking between } \\
\text { pages, coloring, } \\
\text { graphics, } \\
\text { animation, } \\
\text { Query/response }\end{array}$ & $\begin{array}{l}\text { Exchange } \\
\text { of } \\
\text { information }\end{array}$ & $\begin{array}{l}\text { Interactive } \\
\text { (discussion } \\
\text { groups, file } \\
\text { sharing) }\end{array}$ & $\begin{array}{l}\text { Create your } \\
\text { own } \\
\text { groups; } \\
\text { Manage } \\
\text { My groups }\end{array}$ & $\begin{array}{l}\text { Broadcast } \\
\text { (email- } \\
\text { announceme } \\
\text { nts), } \\
\text { Interactive } \\
\text { (email- } \\
\text { discussions) }\end{array}$ & $\begin{array}{l}\text { Online } \\
\text { ads }\end{array}$ & $N / A$ \\
\hline 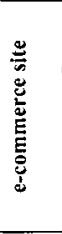 & $\begin{array}{l}\text { Linking between } \\
\text { pages, coloring, } \\
\text { graphics, } \\
\text { animation, } Q / R\end{array}$ & $\begin{array}{l}\text { Browsing } \\
\text { of products }\end{array}$ & $\begin{array}{l}\text { Interactive } \\
\text { (Buyer-to- } \\
\text { vendor } \\
\text { emails) }\end{array}$ & $\begin{array}{l}\text { Personaliz } \\
\text { ation (My } \\
\text { pagc, } \\
\text { Watch list) }\end{array}$ & Hybrid & $\begin{array}{l}\text { Online } \\
\text { ads }\end{array}$ & $\begin{array}{l}\text { shopping } \\
\text { cart, } \\
\text { security, } \\
\text { orders thru } \\
\text { affiliates, } \\
\text { order } \\
\text { tracking, } \\
\text { delivery } \\
\text { options } \\
\end{array}$ \\
\hline 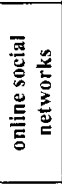 & $\begin{array}{l}\text { Linking between } \\
\text { pages, coloring, } \\
\text { graphics, } \\
\text { animation, Q/R }\end{array}$ & $\begin{array}{l}\text { User } \\
\text { profilcs, } \\
\text { group } \\
\text { highlights }\end{array}$ & $\begin{array}{l}\text { Social } \\
\text { network } \\
\text { groups, } \\
\text { friend-to- } \\
\text { fricnd emails, } \\
\text { chatting, Inst } \\
\text { Mesg } \\
\end{array}$ & $\begin{array}{l}\text { Personaliz } \\
\text { ation (My } \\
\text { page, My } \\
\text { groups, My } \\
\text { friends) }\end{array}$ & $\begin{array}{l}\text { Hybrid } \\
\text { (cmails, } \\
\text { blogs, } \\
\text { fonums, } \\
\text { chatters, RSS } \\
\text { Feed, ctc.) }\end{array}$ & $\begin{array}{l}\text { Online } \\
\text { ads }\end{array}$ & $\mathrm{N} / \mathrm{A}$ \\
\hline
\end{tabular}

Online discussion groups and social networks appear to share similar characteristics with respect to most of the seven elements. The two types of services, however, are different when it comes to content (C2). The focus of discussion groups are for people with similar interests to share information, so the major content is the information of interest (discussions, comments, files). On the other hand, online social networks are a place for people to make friends, so information about friends and groups of friends are the main content. In addition, although both discussion groups and online social networks allow their users to share photos and videos, online social networks usually do not offer services for their members to share document files, which is an important function of online discussion groups. The implication is that, if you want to form a work group, an online discussion group may be a more appropriate choice than an online social network. 


\section{EXAMPLES OF ONLINE SOCIAL NETWORKS}

Various social networking sites exist in today's online communities. Hundreds of social networks websites have been created on the Internet, and new ones continue to pop up every day. A list of more notorious social networks websites can be found on Wikipedia? ${ }^{7}$ Table 4 lists some of the popular online social networking sites. Also included are their respective classification based on the features they provide (thus reflecting the site's main focus), the people count (that is, number of unique visitors), the average stay (or stickiness) of visitors, the month and year when the service was launched, and the number of registered users.

Table 4. Online Social Networking Sites (Compiled from en. Wikipedia.org and

\section{Compete. $\operatorname{com}^{8}$ )}

\begin{tabular}{|l|l|r|r|r|r|}
\hline \multicolumn{1}{|c|}{ Name } & $\begin{array}{c}\text { Classification } \\
\text { (based on the } \\
\text { main focus) }\end{array}$ & $\begin{array}{c}\text { People } \\
\text { Count } \\
(02 / 2007)\end{array}$ & $\begin{array}{c}\text { Average stay } \\
\text { (aka Stickiness, } \\
\text { in minutes) }\end{array}$ & Launched & \multicolumn{1}{c|}{$\begin{array}{c}\text { Number of } \\
\text { Members }\end{array}$} \\
\hline MySpace & General & $59,492,362$ & $25: 58$ & $03 / 2003$ & 26.7 million \\
\hline Facebook & $\begin{array}{l}\text { College/High } \\
\text { School students }\end{array}$ & $12,992,305$ & $13: 12$ & $02 / 2004$ & 11.1 million \\
\hline Xanga & Blogging & $4,476,188$ & $08: 21$ & 1998 & 7.9 million \\
\hline Flickr & Sharing Photos & $14,190,467$ & $06: 17$ & $02 / 2004$ & \\
\hline Linkedln & Business & 506,189 & $06: 56$ & $05 / 2003$ & 354,188 \\
\hline Ning.com & General & 87,252 & $08: 02$ & $10 / 2005$ & $\mathbf{n} / \mathbf{a}$ \\
\hline
\end{tabular}

MySpace is a social networking website which enables users to connect to friends they want to connect with. The site also provides facilities to create personal profiles, blogs, and groups. In addition, the users may choose to upload their photos, music, videos, etc., to their personal page. Facebook is a social networking site initially developed for college and university students, but is now made available to anyone. People may register under various networks, such as school, place of employment, geographic region, etc. LinkedIn is a business-oriented social networking site indented for professionals to network with each other. The main purpose of the site is to allow registered users to maintain a list of connections that are people they know and trust in the business. Xanga is a community of online diaries and journals. Users may create an online journal on the site, to be shared with others. Flickr is a social networking site where users can upload their photos and keep them organized. Users can share photos and stay in touch with friends and family. Thus this site too takes the form of social networking. Ning enables its users to create their own social networks, public or private. They also offer some premium services at an extra cost.

\footnotetext{
http://en.wikipedia.org/wiki/List of social networking websites

${ }^{8}$ www.compete.com
} 


\section{BUSINESS MODELS?}

Why do people and corporations invest in providing a platform for other people to carry out social networking? What does the service provider gain from investing into such platforms? When we look closely and try to analyze online social networking services, there certainly seems to be a business model involved. To understand this, let's first examine some existing business models in Internet applications.

A business model can be defined as: a conceptual tool that contains a set of elements and their relationships, and allows expressing a company's logic of earning money. It is a description of the value a company offers to one or several segments of customers, the architecture of the firm, and its network of partners, all for the purpose of creating, marketing and delivering this value and relationship capital, in order to generate profitable and sustainable revenue streams [7].

\subsection{Primary Revenue Models}

Undoubtedly, one of the most important factors of a business model is revenue collection. Revenue collection is obviously important for sustaining the business, and needs to be modeled carefully. A firm's revenue model decides the methods of revenue collection, and also projects the amount of revenue to be collected. Just like any other businesses, a healthy e-marketplace needs to have a business model that has a working revenue model built in it. There exist five primary revenue models: advertising, subscription, transaction fee, sales, and affiliate [8]. Table 5 shows how these revenue models are applied in some example web-based businesses, and the respective revenue source of each of those businesses.

Table 5. The Five Primary Revenue Models and How Some Businesses Use Them [8]

\begin{tabular}{|l|l|l|}
\hline \multicolumn{1}{|c|}{ Model } & Examples & \multicolumn{1}{|c|}{ Revenue Source } \\
\hline Advertising & Yahoo & $\begin{array}{l}\text { The company (Yahoo) gets paid for putting up advertisements of other } \\
\text { organizations. }\end{array}$ \\
\hline Subscription & $\begin{array}{l}\text { WSJ } \\
\text { Yahoo }\end{array}$ & $\begin{array}{l}\text { The company collects fees from the subscribers in exchange for access to } \\
\text { content or services. }\end{array}$ \\
\hline Transaction Fee & eBay & $\begin{array}{l}\text { The company charges commissions for enabling or executing a } \\
\text { transaction. }\end{array}$ \\
\hline Sales & $\begin{array}{l}\text { Amazon } \\
\text { Yahoo }\end{array}$ & $\begin{array}{l}\text { The company collects revenues from sales of goods, information, and/or } \\
\text { services. }\end{array}$ \\
\hline Affiliate & MyPoints & The company gets paid for referring people to other services/companies. \\
\hline
\end{tabular}

Most of the existing online businesses use hybrid revenue models, and almost all social networks websites use the advertising, subscription, and/or affiliate models. Most online social networks provide free services to the users without charging any use fees. The major source of revenue comes from online advertisements and affiliate programs, and (to a much lesser extent) subscription. Table 6 shows some of the common methods used by online businesses to measure effectiveness of online ads, or to determine the cost. 
Table 6. Common Measures of Revenue Collection in Online Advertisements

\begin{tabular}{|c|l|}
\hline Measures & \multicolumn{1}{|c|}{ Meaning } \\
\hline CPM & $\begin{array}{l}\text { Cost-per-mille is the cost per thousand for a particular site. A Web site that charges } \\
\$ 15,000 \text { per banner and guarantees } 600,000 \text { impressions, for example, has a CPM of } \$ 25 \\
(\$ 15,000 \text { divided by } 600)[9] .\end{array}$ \\
\hline CPA & $\begin{array}{l}\text { Cost-per-action is considered the optimal form of buying online advertising from a } \\
\text { direct response advertiser's point of view. An advertiser only pays for the ad when an } \\
\text { action has occurred. An action can be a product being purchased, a form being filled, etc. } \\
\left.\text { (from Wikipedia }{ }^{9}\right) .\end{array}$ \\
\hline CPI & $\begin{array}{l}\text { Cost-per-impression is a phrase often used in online advertising and marketing related to } \\
\text { web traffic. It is used for measuring the worth and cost of a specific e-marketing } \\
\text { campaign (from Wikipedia } 10 \text { ). }\end{array}$ \\
\hline CPC & $\begin{array}{l}\text { Cost-per-click is an Internet marketing formula used to price ad banners. Advertisers will } \\
\text { pay Internet publishers based on the number of clicks a specific ad banner gets [9]. }\end{array}$ \\
\hline
\end{tabular}

Affiliate programs work in a way similar to online ads. When the user clicks an ad hosted on the web site, the user gets redirected to the advertiser's web site. Generally the URL used for redirection has the referral code, using which the advertiser's site can understand whom to give the referral points. The hosting site can then get money depending on the contract between the two parties.

It is apparent that, whatever revenue model is used in an e-business, it is essential to keep the customers hooked to the site. Most of the content-driven sites and those sites that provide a platform or service for carrying out online businesses (whether $\mathrm{B} 2 \mathrm{~B}$ or $\mathrm{C2C}$ ) earn a good share of their revenue from the advertising endorsements. Therefore, attracting advertisers to the site becomes an essential part of the site's business model. Now if an advertiser wants to e-advertise a company's product, on which sites should the ads appear? Of course people would like to advertise on sites that may reach a large number of potential customers.

\subsection{The Five Forces Model}

In this sub-section, we explore the Porter's Five Forces Model, and later apply the model to an online social networking site. The Five Forces Analysis is a framework for business management developed by Michael Porter in 1979 [5]. The analysis examines those forces close to a company that affect its ability to serve its customers and make a profit. A change in any of the forces normally requires a company to reassess the marketplace [5]. The "five forces" of a business are shown in Fig. 1. Buyer power is high when buyers have many choices from whom to buy, and low when their choices are few. As a provider of products and services, an organization wishes to reduce buyer power [1]. Supplier power is high when buyers have few choices from whom to buy, and low when their choices are many. Supplier power is the converse of buyer power [1]. The threat of substitute products or services depends on buyer propensity to substitute, relative price performance of substitutes, buyer switching cost, and the perceived level of product differentiation [5]. The threat of substitute products or services is high when there are many alternatives to a product or service, and low when there are few alternatives from which to choose [1].

\footnotetext{
${ }^{9} \mathrm{http} / / /$ en.wikipedia.org/wiki/Cost_Per_Action

${ }^{10} \mathrm{http}: / /$ en.wikipedia.org/wiki/Cost_Per_Impression
} 
The threat of new entrants is high when it is easy for new competitors to enter a market, and low when there are significant entry barriers to entering a market [1]. The rivalry among existing competitors is high when competition is fierce in a market (low when competition is more complacent [1]).

\subsection{Analysis of Ning.com}

In this sub-section, we apply the Five Forces Model to an online social networking site, Ning.com, as an illustration of how the model may be used in analyzing

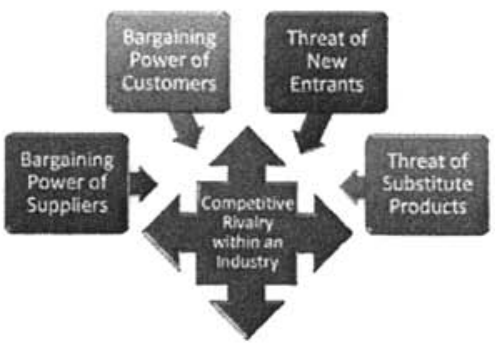

Figure 1. Porter's Five Forces Model $^{11}$ the business model of online social networks sites. Ning provides its users free service for them to create and host their own social networks on ning.com. The free services, however, are limited (for example, limited disk space). Like most of the social networking sites, online ads are placed on the user-created social network pages, in order for Ning to earn some revenue from the advertisers. Another revenue model used by Ning is to provide optional "premium services" to the users by charging a monthly fee.

As illustrated in Figure 2, the main buyers are advertising companies and the subscribers of "premium services". The buyer power is high since the advertisers and the premium users may get the same services from other social networks sites.

It is interesting to note that the main supplier to this social networking site is the visitors who visit Ning's social networks, mainly because the number and types of people visiting the site determine how attractive the site is to potential advertisers. In comparison, other types of suppliers that supply the server hardware, software, or network bandwidth to the site play a relatively less significant role. With respect to the suppliers being the visitors, the supplier power is high, mainly because there exist many other social networking sites (such as MySpace.com) the visitor may choose to visit. In order to reduce the supplier power, Ning will need to provide attractive services to its users, to allow them to create attractive social networks to attract more visitors. When the number of members grows, the supplier power will also go down, because most people prefer to join a social network site where his or her friends are already members.

The threat of substitute products or services is high in this case as there are many other alternative services available to the buyers. Here the switching cost will be the "social networks" that are hosted on Ning. Currently there is no way of moving the whole network from one service provider to another, making the switching cost high when a member of a Ning social network decides to leave and join another provider's network.

The threat of new entrants in this case is high. Lots of online social networking sites are being/have been launched, since the time Ning was launched, and the trend

" http://en.wikipedia.org/wiki/Image:Porters_five_forces.PNG 
continues. A strong entry barrier as such is still non-existent in this case. Since there are many similar online social networks sites, the rivalry among existing competitors is fierce.

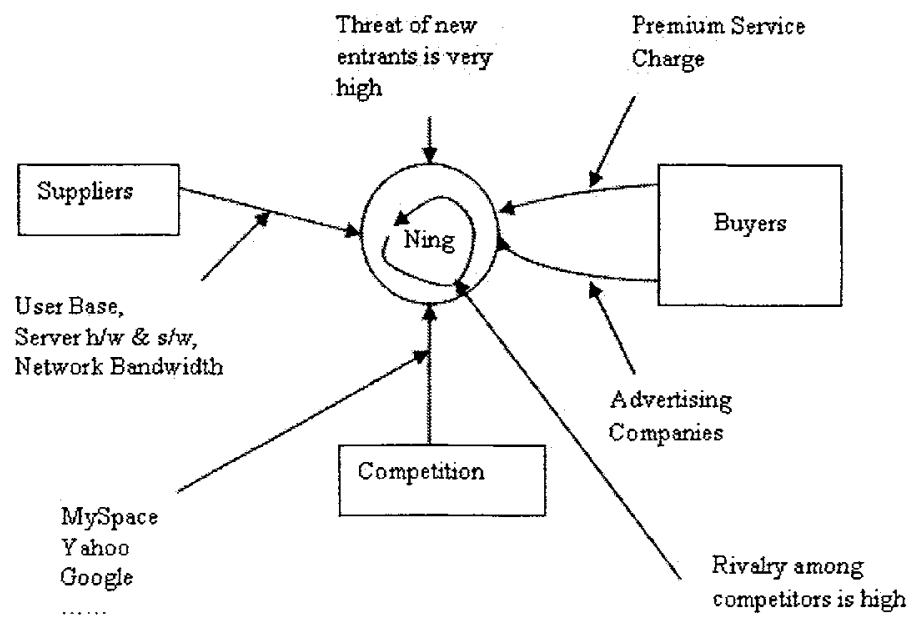

Figure 2. Conceptual View of Porter's Five Forces Model when Applied to Ning.com

In summary, revenues generated from online ads and subscription to premium services form the basis of the revenue model of Ning. This is also true to most of the other online social networking site, such as MySpace, flickr, LinkedIn, Facebook, etc. Leonard Lodish, a Wharton marketing professor, points out that in case of MySpace and Facebook, the cost of gaining new customers is practically nothing because users join voluntarily and provide their own content through their profiles. In addition, the cost of running the sites' web servers is relatively low. If a classic advertising or subscription revenue model is used, low-cost social network sites could be highly profitable [10].

\section{SUMMARY AND FUTURE WORK}

Our analysis of the primary revenue models indicates that advertisements, affiliate programs, and subscription-based services remain the main source of revenues for social networking websites. The larger the number of people using an online social network service, the more revenue may be generated for the service provider.

The Five Forces analysis reveals that, in order for an online social network site to remain competitive, it must provide innovative and quality services to recruit new users and retain existing members. The quality of services and features that a service provider provides will determine whether people would be hooked to the social networking site. Also revealed by the analysis is the fierce competition in the online 
social networking industry. More online social networking services are now giving their members some referral points for referring friends to the service. In the future online social networking sites may integrate other services, such as selling products, into their business model, in order to generate revenue.

This paper represents our work in progress in the area of analyzing online social networking services using existing business models. We plan to extend the existing model (e.g., the 7C framework) to accommodate other types of social networks, such as Wikipedia.com, where collaboration among participants makes it unique and different from other social networking sites. Additional interface elements such as collaboration may need to be added to extend the $7 \mathrm{C}$ framework to accommodate all types of online social networking services.

\section{REFERENCES}

1. S. Haag, M. Cummings, and A. Phillips, Management Information Systems for the Information Age, 6th edition, Ch. 2, Major Business Initiatives (2005).

2. B. Francisco, Cracking the social network code (July 25, 2006). http://www.marketwatch.com/News/Story/Story.aspx?guid=\%7BAA7046A8-9D8B471B-852E-5B6C6100ED40\%7D (Accessed March 27, 2007).

3. R. Naraine, Social Networks In Search of Business Models (February 13, 2004). http://www.internetnews.com/bus-news/article.php/3312491 (Accessed April 12, 2007).

4. J. Rayport and B. Jaworski, Introduction to E-Commerce (McGraw-Hill: New York, 2001).

5. Porter 5 forces analysis. http://en.wikipedia.org/wiki/Porter_ 5 forces analysis (Accessed April 1, 2007).

6. Y.E. Lee and I. Benbasat, A Framework for the Study of Customer Interface Design for Mobile Commerce, International Journal of Electronic Commerce. Volume 8, Number 3, pp.79-102, (2004).

7. A. Osterwalder, What is a business model? (November 5, 2005). http://www.businessmodeldesign.com/publications/The $\% 20$ Business $\% 20$ Model $\% 200$ ntol ogy $\% 20 \mathrm{a} \% 20$ proposition $\% 20$ in $\% 20 \mathrm{a} \% 20$ design $\% 20$ science\%20approach.pdf (Accessed April 8, 2007).

8. K.C. Laudon and C.G. Traver, E-commerce: business, technology, society, $3^{\text {rd }}$ edition (Prentice Hall: 2006), pp.62-63.

9. TKB-4U, Europe, Ad Resource Glossary (2001-2007). http://www.tkb4u.com/advertising/adglossary.php (Accessed April 12, 2007).

9. The Wharton School of the University of Pennsylvania, Knowledge@Wharton (2006). http://knowledge. wharton.upenn.edu/article.cfm?articleid $=1463 \&$ CFID $=9333991 \&$ CFTO

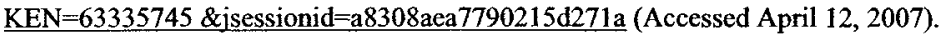

